\title{
References
}

1. Abdokov, Yu. (2009). Musical poetics of choreography: Plastic interpretation of music in choreographic art. View composer. Moscow: MGAKH, RATI-GITIS [in Russian].

2. Arkhipova, M.V. (2016). On the rhythmic nature of the musical gesture: to the formulation of the problem. Vestnik Tomskogo gosudarstvennogo universiteta. Kul'turologiya i iskusstvovedeniye, 3, 108-113 [in Russian].

3. Askin, I. (1966). The Problem of Time: Its Philosophical Interpretation. Moscow: Mysl' [in Russian].

4. Vyshinsky, V. (2012). Symphonism by D. Shostakovich and G. Mahler: movement as a structuring and musical-dramatic factor. Extended abstract of candidate's thesis. Kiev [in Ukrainian].

5. Gnativ, N. (2014). Thematic rhythm as a factor in the organization of the musical movement in the instrumental writings of Paul Gindemit. Naukovyy visnyk Natsional'noyi muzychnoyi akademiyi Ukrayiny imeni P. I. Chaykovs'koho: zb. nauk. pr. Kyiv, 111, 42-51 [in Ukrainian].

6. Zharkova, V. (2014). About movement in music, or about "achieving what they have not achieved before"... Naukovyy visnyk Natsional'noyi muzychnoyi akademiyi Ukrayiny imeni P. I. Chaykovs'koho: zb. nauk. pr. Kyiv, 111, 3-13 [in Ukrainian].

7. Karachevtseva, I. (2014). Movement as a factor in organizing a musical whole in Sonata for violin and piano f-dur $f$ Mendelssohn. Naukovyy visnyk Natsional'noyi muzychnoyi akademiyi Ukrayiny imeni P. I. Chaykovs'koho: zb. nauk. pr. Kyiv, 111, 7582 [in Ukrainian].

8. Kurt, E. (1931). Basics of linear counterpoint. B.V. Asafiev (Ed.). (Z. Ewald, Trans). Moscow: Gos. muz. izdatel'stvo [in Russian].

9. Medushevsky, V. (1980). Man in the mirror of intonation form. Sovetskaya muzyka. Moscow, 9, 34-48 [in Russian] Russian].

10. Ruchevskaya, E. (2002). Movement and rhythm (instead of the preface). Ritm i forma: sb. statey. St. Petersburg, 5-9 [in

11. Tsaregradskaya, T. (2016). To the problem of physicality in modern musical culture: the concept of musical gesture Khudozhestvennaya kul'tura. Elektronnoye period. rets. nauch. izd. Moscow: Gosudarstvennyy institut iskusstvoznaniya, 2 (18). Retrieved from http://artculturestudies.sias.ru/2016-2-18/yazyki/5042.html [in Russian].

12. Chirkov, S.E. (2017). Gesture syntax: the concept of deconstruction in musical interpretation. Vestnik Akademii Russkogo baleta im. A.YA. Vaganovoy. Moscow, 6, 119-127 [in Russian].

13. Hatten R.S. (2004). Interpreting musical Gestures, Topics and Tropes: Mozart, Beethoven, Schubert. Bloomington: Indiana university press.

14. Tarasti E. (1985). Music as sign and process. Analytica: Studies in the description and analysis of music. Uppsala. P.97 $-115$.

15. Truslit A. (1938). Gestaltung und Bewegung in der Musik. Berlin, Lichterfelde. URL: http://www.haskins.yale.edu/sr/SR111/sr111_21.pdf

Стаття надійшла до редакиії 23.06.2019 p.

УДК 792:791.221.28]:316.346

Гайдаш Анна Владиславівна.

кандидат фрілологічних наук, доцент, доцент кафедри германської філології

Київського університету імені Бориса Грінченка

ORCID: 0000-0001-8200-2875

gaidash_anna@ukr.net

\section{ПОЕТИКА ПІЗНЬОї ЗРІЛОСТІ У ВИСТАВАХ КИЇВСЬКОГО АКАДЕМІЧНОГО МОЛОДОГО ТЕАТРУ}

Метою дослідження є аналіз поетичної площини пізньої зрілості у виставах Київського академічного Молодого театру з метою осмислення художніх репрезентацій літнього віку в сучасному культурному просторі. Методологічна основа дослідження застосовує культурно-історичний і компаративний підходи, синтез і узагальнення. Наукова новизна роботи полягає у тому, що у вітчизняній гуманітаристиці вперше здійснено спробу аналізу поетики пізньої зрілості у спектаклях Київського академічного Молодого театру на матеріалі вистав «Поступися місцем!» і «Сталкери». Попри очевидну (національну, географічну, хронологічну) відмінність проаналізованих творів їхнім спільним знаменником виявлено трагічну велич літнього віку дійових осіб. Висновки. Обґрунтовано, що репрезентації літнього віку на сцені породжені викликами сьогодення, зокрема збільшенням середньої тривалості життя, усвідомленням самотності і власної непотрібності літніми людьми. Доведено, що ознаками поетики пізньої зрілості у виставах Молодого театру є диссункціональна взаємодія літніх персонажів із соціумом і молодшим поколінням, стратегії старіння і спогади старших дійових осіб, топос дому, спільний для драм «Поступися місцем!» і «Сталкери» образ вокзалу/метро, трагікомічна тональність, мінімальний конструктивізм сценографрії та лейтмотивне використання популярного музичного ряду.

Ключові слова: пізня зрілість, театральна вистава, міжпоколіннєвий конфлікт, простір дому, трагікомедія.

Гайдаш Анна Владиславовна, кандидат фрилологических наук, доцент, доцент кафедры германской филологии Киевского университета имени Бориса Гринченка

Поэтика поздней зрелости в спектаклях Киевского академического Молодого театра

Целью исследования является анализ поэтики старости в спектаклях Киевского академического Молодого театра с целью осмысления художественных представлений о пожилом возрасте в современной культуре. Методологическая основа исследования использует культурно-исторический и сравнительный подходы, синтез и обобщение. Научная новизна работы заключается в том, что в украинской гуманитаристике впервые предпринята попытка анализа поэтики поздней зрелости в спектаклях Киевского академического Молодого театра на материале спектаклей «Уступи место!» И «Сталкеры». Несмотря на очевидные различия проанализированных произведений их общим знаменателем является трагическое величие пожилого возраста действующих лиц вопреки давлению бесчеловечности и экономическим кризисам. Выводы. Обосновано, что представления о «третьем возрасте» в спектаклях порождены вызовами современности, в частности, увеличением средней продолжительности жизни, осознанием одиночества и собственной ненужности пожилыми людьми. Доказано, что составляю- 
щими поэтики поздней зрелости в спектаклях Молодого театра являются дисфункциональное взаимодействие пожилых персонажей с социумом и младшими поколениями, стратегии старения и воспоминания старших действующих лиц, топос дома, общий для драм «Уступи место!» и «Сталкеры» образ вокзала / метро, трагикомическая тональность, минимальный конструктивизм сценографии и лейтмотивное использования популярного музыкального ряда.

Ключевые слова: поздняя зрелость, театральное представление, межпоколенческий конфликт, пространство дома, трагикомедия.

Gaidash Anna, candidate of philological sciences (PhD), associate professor, associate professor of the department of Germanic philology at Borys Grinchenko Kyiv University

Poetics of late adulthood in the performances of Kyiv Academic Molodyi Theatre

The purpose of the article is to analyze the poetics of old age in the performances of Kyiv Academic Molodyi Theater to consider artistic representations of the elderly in contemporary Ukrainian culture. The methodology of the article are mixed: cultural and historical data processing, close reading technique, comparative approach, synthesis, and generalization. The academic novelty of the article demonstrates the first endeavor in the Ukrainian humanities to study poetical dimensions of late adulthood representations in the performances "Make Way!" and "The Stalkers" in Kyiv Academic Molodyi Theater. The performances are based correspondingly on Viña Delmar's screenplay "Make Way for Tomorrow" (1937) and Pavlo Arie's drama "At the beginning and at the end of times" (2013). Despite the obvious (national, geographical, chronological) differences of these dramatic works, their common denominator is the tragic grandeur of the elderly characters in spite of intergenerational inhumanity and economic crises. Conclusions. The author argues that the frequency of the representations of the "third age" onstage is generated by the challenges of our times, in particular, by the increased average life expectancy, the awareness of loneliness and worthlessness by the elderly. The author singles out the following poetic components of late adulthood in the performances of Molodyi Theater: the intergenerational conflicts between elderly and younger characters, the strategies of aging and memories of old dramatis personae, the topos of home, the common metaphor of the railway station and metro, tragicomic tonality, minimal constructivism of scenic design and leitmotif use of musical accompaniment.

Key words: late adulthood; theatrical performance; intergenerational conflict; topos of home; tragicomedy.

Актуальність теми дослідження. У Київському академічному Молодому театрі зі сторічною історією, хоча і розірваною ланцюгом часу, вистави виділяються різноманітними стилями, фрормою і тематикою. Спектаклі «Поступися місцем!», «Сталкери», «Дівочий виноград», «Серпень: округ Осейдж», «Загадкові варіації», «Афрінські вечори», «Соло для годинника з боєм» об'єднують потужні образи літніх дійових осіб, драматична доля яких провокує питання і рефлексії щодо старості або «третього віку». Відображаючи особливості буття людини й тенденції поступу людства загалом, мистецтво, і особливо театр, не можуть оминути й важливої демографічної зміни - збільшення тривалості життя індивіда. Саме тому дослідження змістового навантаження пізньої зрілості людини - актуальний виклик сьогодення. Знайомство із затребуваними виставами сучасного театру дає змогу виокремити особливості сценічного відтворення персонажів літнього віку.

Аналіз досліджень і публікацій. Підвищення інтересу сучасності до питань «третього віку» спостерігається передовсім у геронтологічних і споріднених дисциплінах, тоді як гуманітаристика, і культурологічні студії зокрема, лише починають вивчати окремі виклики пізньої зрілості. На сьогодні існують поодинокі зарубіжні розвідки М. М. Гуллетт та В. Б. Ліпскоум з питань театральних репрезентацій геронтогенезу $[9 ; 11]$.

Мета дослідження. Актуальність питань пізньої зрілості, популярність п'єс, присвячених літньому віку, та брак комплексних робіт з їх аналізу визначають мету даної статті у вивченні художньопоетичної наповненості пізньої зрілості у виставах Київського академічного молодого театру за творами В. Дельмар та П. Ар'є. Завдання статті вбачаємо у дослідженні таких семантико-поетикальних форм репрезентації «третього віку» у спектаклях «Поступися місцем!» і «Сталкери», як взаємодія літніх персонажів із соціумом і молодшим поколінням, стратегії старіння, які вони обирають, топос дому, сценічний дизайн і музичне оформлення.

Виклад основного матеріалу. Тему літніх батьків, які мешкають із своїми дітьми, висвітлює вистава «Поступися місцем!» за сценарієм американської письменниці Віньї Дельмар (1937), затребувана і за часів Радянського Союзу (відома як «Далі - тиша»), і актуальна для сучасного українського глядача (у Молодому театрі прем'єра відбулася 9 червня 2016 р.). Режисерська робота Д. Весельського, підкріплена мінімалістським рішенням сценографії та відповідним музичним оформленням, створює сумну комедію, в якій передано як американський дух часу Великої депресії, так і універсальну трагедію старих батьків та їх дорослих дітей. Успіх спектаклю значною мірою завдячує парі прекрасних акторів, які грають літнє подружжя Куперів (Люсі і Барклея), народним артистам України, - Тетяні Стебловській і Ярославу Гаврилюку.

У виставі простежується фрінансово-економічна залежність літніх людей від своїх дітей та те, як змінюється ставлення дітей до батьків залежно від фінансового становища останніх. Породжений соціальними проблемами, театр завжди відбивав світ, який швидко змінювався, отож і п'єса «Поступися місцем!» відображає ринкові умови, які проникають і у родину. За словами Т.Стебловської: «Ця вистава про двох людей. Про життя, про сім'ю, про те, що люди стали дуже черствими. Гроші заступили місце почуттів» [7, 41]. Міжпоколіннєвий конфлікт поглиблюється ще й мотивом межовості поколінь: старі Купери - носії патріархальних цінностей попереднього періоду, світогляд же їхніх дітей результат нової доби грошей та успіху, часу, коли «купується і продається все, навіть у сімейних стосунках, оформлених партнерськими контрактами» $[3,23]$.

Втративши закладений будинок, старе подружжя Куперів (75 років), яких Бог благословив 5-ма дітьми, вимушене просити фінансової підтримки у своїх нащадків (у п'єсі задіяні 4: Роберт, Неллі, Кора, Джордж і його дружина Аніта). Однак для них батьки - зайвий тягар, який вони «не можуть собі 
дозволити», тому шукають відмовки, коли Батько звертається до них із проханням зняти їм квартиру. Старий Купер дорікає дітям: «Ми чомусь могли піклуватися про вас більше 40 років. При цьому нас-то було двоє, а вас - п'ятеро. Тепер же, коли ми з мамою розраховували, що ви - вп'ятьох - зможете попіклуватися про нас двох, я бачу, що ця ідея не викликає у вас особливого ентузіазму» [2]. Обговорюючи між собою ситуацію, що склалася з батьками, молодші Купери висловлюють тези, що ілюструють кардинальну зміну у ставленні до батьків нового покоління, викликаючи миттєву алюзія на шекспірівську трагедію короля Ліра. На прохання Джорджа виявити до батьків повагу хоча б за те, що вони дали йому життя, Роберт зауважує, що не просив його народжувати, а сам Джордж говорить про те, що «в моєму віці сімейні прив'язаності зберігаються доти, доки їх не починають перевіряти» [2]. Жоден не знайшов можливості взяти до себе обох батьків. Тому старих людей, які за 50 років жодного разу не розлучалися й досі люблять одне одного, розділили діти. Ставлення ж до старості в цих родинах дітей літнього подружжя Куперів далеке від пієтету: крики й ігнорування, нарікання, що Мати заважає, лайка через поламані окуляри Батька, який вимушений жити на кухні, відтворюють реалістичність міжпоколіннєвого конфлікту. Наполягаючи, аби Мати сиділа в кімнаті, Джордж виявляє, що соромиться її, як і онука, яка перестає приводить своїх друзів. Аніта, дружина Джорджа, звинувачує стару в автокатастрофрі, якої б не сталося, якби вона не чіпала друзів онуки - п'єса стає чи не апогеєм викриття ейджистської сутності американського суспільства доби Великої депресії.

Старі Купери - не єдині літні персонажі у спектаклі. Літнє подружжя Левицьких демонструє іншу модель можливого майбутнього. Старий Левицький - власник аптекарської крамнички: «Я теж пишаюся моїми дітьми, поки вони залишають мене у спокої... Вони не потребують мене, то чому я маю потребувати їх? Я маю цю крамничку з невеликим доходом. Є дружина. Іноді вечорами я люблю грати на скрипці. Я ж нікому не заважаю, чи не так?.. Ось і все. А більше мені нічого не потрібно» [2]. Родина Левицьких не потрапила в економічну залежність від дітей, бо має джерело прибутку. Однак для Купера такий розвиток подій неможливий: завод, на якому він пропрацював 47 років, закрили. Вікова дискримінація і фрізична неспроможність виконувати ту роботу, яку все ж пропонують (це переважно примітивна, але важка фрізична праця), веде до того, що літні люди, хоча й мають високу мотивацію для того, аби продовжити свій трудовий шлях, і досвід, який міг би компенсувати певне зниження продуктивності, здебільшого лишаються безробітними [4]. Старий Купер належить саме до такої мало захищеної категорії: його намірам знайти роботи, аби нарешті знову жити зі своєю дружиною, так і не судилося справдитися. Прощання Куперів у кінці п'єси демонструє, що хоч Батько й зберігає надію на працевлаштування, але свідомий її ілюзорності.

За умов трансформації міжпоколіннєвих стосунків, за якої біблійний постулат поваги до батька залишається в минулому, закономірністю стає поява теми геріатричних установ. Стара пані Купер дуже боїться «богадільні», навіть змушує сина Джорджа присягнути ніколи ії туди не відправляти, але за логікою п'єси для неї - це єдиний шлях, тож врешті саме до геріатричного будинку, де, як кажуть діти, вона знайде товаришок свого віку й де їй буде дуже добре, вона добровільно і йде, аби її чоловік мав шанс одужати.

Кульмінаційним моментом вистави є коротка зустріч Люсі та Барклея Куперів у місті їхньої молодості - де вони провели свій медовий місяць. Спогади літнього подружжя, своєрідний «перегляд життя», сприяють життєствердженню та адаптації до геронтогенезу. Саме тут і досі закохані один в одного герої розуміють, що розстаються навіки. І усвідомлюють, наскільки глухими до них виявляються власні діти.

Потужним символом у площині поетики пізньої зрілості є образ вокзалу, що уособлює транзитний стан - кінець одного періоду та початок іншого: «Миготять на задньому плані семафори, простір заповнено коробками і візками... і міцно обійнявшись, стоять Люсі та Барклей Купери, чи то зустрівшись після розлуки, чи то прощаючись назавжди» [7, 41]. Додамо, що обрана символічна ємність декорацій (вокзальні транспортні візки із нагромадженням шухляд) символізує транзитний стан літніх дійових осіб, що на побутовому рівні виражає бездомність Люсі і Барклея, а на метафізичному - перехід у небуття.

Попри те, що літнє подружжя Куперів наражається на подібне ставлення від власних дітей, вони не замикаються в собі й не тікають від реальності в минуле, хоча стара Мати часто робить вигляд, ніби нічого не сталося, що, як сама каже, є привілеєм старості. Загалом, демонструючи пасивну стратегію старіння, вони знаходять у собі здатність прийняти реальність, але опору, яка дає сили продовжувати жити, здибують не у своїх дітях, як це зазвичай роблять літні люди, особливо жінки, а одне в одному й щасливих роках, прожитих разом - така стратегія можлива за умов, коли подружжя - однолітки і завдяки цьому мають шанси зустріти старість разом.

Інші виміри пізньої зрілості представлені у виставі «Сталкери» за п'єсою українського драматурга Павла Ар'є «На початку і наприкінці часів» (прем'єра у Молодому театрі мала місце 18 травня 2015 р.). Дія «Сталкерів» відбувається у Чорнобильській зоні відчуження: поперемінно на кухні та на подвір'ї сільської хати 86-річної баби Прісі або Єфросинії Гаврилівни Чумак. Слава (дочка баби Прісі) та Вовчик, її 28-річний син, яких покинув чоловік та батько, живуть разом зі старою. Час від часу їх відвідує дільничний (четвертий і останній персонаж). 
У першій частині вистави показаний неспішний перебіг життя родини, в якому сучасність перемежована з минулим у вигляді флешбеків та галюцинацій баби Прісі після вживання блакитних грибів. Повернувшись до матері після невдалої спроби переселення, хвора Слава дослуховується старої, однак і між ними повсякчасно відбуваються дрібні побутові конфлікти. Пріся вважає доччине покоління втраченим, позбавленим вірі та дії. Зломлена зрадою чоловіка і недієздатністю сина, зріла жінка і мати обирає інфантильність, сповідуючи філософію неспротиву: «Треба тихо сидіть і нікому на очі не лізти, тоді нас лихо обійде», що викликає обурення баби Прісі: «Від біди не ховатися, а жить з нею навчитися треба» [1, с. 46]. У другій частині дізнаємося, що депутат, який приїхав розважатися на Чорнобильське «сафарі», полював на Вовчика та поцілив з рушниці. Попри всі знахарські вміння Прісі хлопець помирає, а стара вбиває дільничного, який відмовляється допомагати їй, а потім кінчає життя самогубством. Слава божеволіє, зрозумівши, що трапилося з її рідними людьми. В останній сцені трагедії всі чотири персонажі їдуть у вагоні секретної гілки метро, яка, за словами баби Прісі, проходить під її хатою. Омріяна Вовчиком втеча у метро є логічним фріналом трагедії Ар'є: динамікою руху поїзду та розмовою усіх дійових осіб п'єси у вагоні драматург ніби стверджує циклічність життя, коли людина житиме на початку і наприкінці часів.

У розгалуженій поліфонічній виставі «Сталкери» портрет головної героїні заслуговує на окреме дослідження. Роль старої жінки блискуче виконує заслужена артистка України Ірма Вітовська (двічі молодша своєї героїні), яка отримала «Київську Пектораль» як найкраща актриса року. Американська дослідниця віку М.Гуллетт зауважує, що грати старшого персонажа у драматичному театрі набагато складніше, ніж молодшого $[9,168]$. Стереотипні уявлення про літній вік можуть зашкодити, а на сцені пізня зрілість потребує «широкий діапазон чуттєвих спогадів і психологічного ставлення до минулого» $[9,170]$. В інтерв'ю І.Вітовська зізнається, що у творенні образу Прісі вона підсвідомо використала тілесні рухи, жести, пластику і гумор своїх рідних бабусь [5]. Так фрормується образність пізньої зрілості, у з'ясуванні якої годі знайти довідника або суфлерського примірника, як пише Гуллетт: «Можна виробити літній вік як у житті, так і на сцені, лише проживши певний відрізок часу» [9, 171].

Вивчаючи геронтомаркери старіння образу баби Прісі, відзначимо її непохитну силу духу, що надає літній людині можливості протистояти безбожності оточуючої їі дійсності. Це виражається як в іронічних репліках головної героїні («старі бабусі радіації не бояться, навпаки - радіація дуже сильно бабусям полєзна» $[1,27])$, так і в її вірі в магію Полісся, органічною частиною якого вона є: «Значиться, у нас тут ще з давніх часів усякі чудеса творилися. Русалки, мавки, духи польові, нечесть усіляка жила» $[1,39]$. Наведемо деякі відгуки, дотичні до геронтопортрету протагоністки: за Г.Протасовою, «баба Пріся свідомо асоціює себе лише з покинутою землею, яка парадоксально дає їй сили для виживання. Образ баби Прісі - це тип українця, яким він сам, напевно, хотів би себе бачити. Головний «козир» цього типажу - вміння перетворювати власні вади й нещастя на зброю, а не лише мовчки потерпати від них» [6]. Театральний оглядач пише: «тут живе душа тисячоліть - 86-річна бабця, яка і про інопланетян розкаже, і як кіношний спецназівець ножик в горло ворога метне, навчить як жити, і як вижити, не втрачаючи себе» [8].

Поетику пізньої зрілості у виставі «Сталкери» формує сюрреалістична складова тексту Ар'є: низка сцен оприявнює холотропний стан свідомості дійових осіб, баби Прісі зокрема. А. КоженьовськаБігун називає це «народною космологією» [10, 217], яка є спадком сімейної традиції головної героїні. Так, звертаючись до Вовчика, який у своєму віці залишається дорослою дитиною, баба Пріся передає свої знання онукові: «Русалки - вони не погані. Можуть бути опасними, та якщо ти їм заспіваєш, віночок сплетеш або рушничок білий подаруєш, то вони тебе нівжизнь не тронуть, навпаки, про біду попередять, від врогів сховають... То мене моя бабка навчила - звали її Стефанія...» [1, 62]. У цій репліці важливими $є$ спогади літньої протагоністки про власну бабусю-травницю, яка передала їй традиційні вірування. Пріся так пояснює тяглість часу: «Весь остальний світ вже давно живе за прямим часом, у них немає ні дня, ні ночі, кожен спить і працює, коли хоче, а наш час круглий - встаємо з сонцем, лягаємо з місяцем... Весь світ спішиться кудись всігди спізняється, бо час прямий. У нас спішитися нікуди, у нас час круглий... Ми живемо на початку і наприкінці часів...» [1, 62-23]. На думку КоженьовськоїБігун, зона, унаочнена подвір'ям баби Прісі, постає паралельним світом до решти справжнього світу, або «не-зони», як його називають дійові особи «Сталкерів».

Назва спектаклю Жиркова корелює із назвою першої сцени тексту Ар'є. У зав'язці Вовчик розповідає, як подружився із сталкерами, які і розказали йому про «не-зону». Однак, інтерпретація сталкінгу режисером виходить за межі поняття, закладеного ще братами Стругацькими у художній літературі: «I «сталкери» - це не безбашенні неформали-мандрівники, що лазять заборонними лісами, а всі ми, котрі з покоління в покоління рухалися замкненим колом, не в змозі його розірвати» [5].

До поетичної площини пізньої зрілості у виставі «Сталкери» відносимо інкорпорацію фрагментів пісні «Ти, земле моя» (слова Ю.Рибчинського) у виконанні Софії Ротару, якою заслуховується і яку наспівує баба Пріся. Щемливий лейтмотивний приспів додає нотку ліризму до страшної трагедії та переконує, що місцем катастрофи є не лише хата головної героїні, і не лише Прип'ять, а вся країна.

Наукова новизна роботи полягає у тому, що у вітчизняній гуманітаристиці вперше здійснено спробу аналізу поетики пізньої зрілості у спектаклях Київського академічного Молодого театру на матеріалі вистав «Поступися місцем!» і «Сталкери». Попри очевидну (національну, географічну, хроно- 
логічну) відмінність проаналізованих творів їхнім спільним знаменником виявлено трагічну велич літнього віку дійових осіб, незважаючи на брак людяності й економічні кризи.

Висновки. У меншій мірі, ніж у спектаклі «Поступися місцем!» семантика літнього віку у «Сталкерах» представлена міжпоколіннєвими непорозуміннями, але більшою мірою - трагічністю фріналу. Розділені просторовими (США/Україна) і часовими (1930і роки/наш час) координатами, поетика пізньої зрілості у виставах Молодого театру демонструє активну стратегію старіння жіночих персонажів - Люсі Купер та баби Прісі, яким притаманна іронічна самостереотипізація. Спогади літніх дійових осіб, які реконструюють окремі історичні епохи минулого століття, є органічною складовою поетики пізньої зрілості. Як показують проаналізовані вистави, ключовою умовою продуктивного «третього віку» $\epsilon$ особистий простір і власний дім, які створюють прихисток і осередок натхнення у старості. Крім вербальної складової, особливостями аудіовізуального відтворення поетики пізньої зрілості у виставах «Поступися місцем!» і «Сталкери» є спільний для обох драм простір вокзалу/метро, мінімалізм декорацій та пронизливо-ліричне музичне оформлення. Попри заявлені в афішах жанрові характеристики спектаклів (сумна комедія Дельмар і специфічна комедія Ар'є), проведений аналіз дає підстави вважати обидві вистави трагікомедіями. Поетика пізньої зрілості у виставах Київського академічного Молодого театру, продемонстрована моделями міжгенераційної взаємодії літніх персонажів із молодшими, топосом дому, стратегіями старіння і «переглядом життя», закликає сучасного глядача до співчуття, а також до особистих, соціальних і політичних змін.

\section{תimepamypa}

1. Ар'є П. На початку і наприкінці часів. Баба Пріся та інші герої. Брустури : Дискурсус, 2015. С. 15-95.

2. Дельмар В. Дальше - тишина...[Электронный ресурс] / пер. с англ. и сценическая ред. К. Раппопорта. Книжная полка : сайт. URL: http://bookworm-e-library.blogspot.com/2012/07/1978-vina-delmar-make-way-for-tomorrow.html (дата обращения: 28.08.2018).

3. Дьяченко Л. И. Аспекты сущности геронтологии в контексте социально-философрского анализа. Вестник Вятского государственного гуманитарного университета : науч. журн. Киров, 2009. № 3 (4). С. 21-24.

4. Кірнос І. Економічна активність людей похилого віку: різноманіття ракурсів [Електронний ресурс]. Науковий вісник Міжнародного гуманітарного університету. Серія: Економіка і менеджмент. Одеса, 2017. Вип. 25-2. C. 72-77. URL: http://www.vestnik-econom.mgu.od.ua/journal/2017/25-2-2017/17.pdf (дата звернення: 28.08.2018).

5. Плохотнюк Н. «Сталкери» або як радіоактивний гумор межує з правдою нашого життя [Електронний ресурс] Вечірній Київ. URL: https://vechirniykiev.com.ua/news/stalkery-abo-yak-radioaktyvnyy-humor-mezhuye-z-pravdoyu-nashoho-zhyttya (дата звернення: 28.08.2018).

6. Протасова Г. Павло Ар'є. Баба Пріся та інші герої [Електроннй ресурс]. Критика. URL: https://krytyka.com/ua/reviews/baba-prisya-ta-inshi-heroyi (дата звернення: 28.08.2018).

7. Український театр / голов. ред. Н. Соколенко. 2016. №. 3. 48 с.

8. Хоменко К. «Баба Пріся» Павла Ар'є [Електронний ресурс]. Live Journal. URL: https:/theaterkiev.livejournal.com/26332.html (дата звернення: 28.08.2018).

9. Gullette M. M. Acting Age on Stage. Aged by culture. Chicago : The University of Chicago Press, 2004. P. 159-178.

10. Korzeniowska-Bihun A. Zona czarnobylska we współczesnej dramaturgii ukraińskiej. Teatr historii lokalnych w Europie Środkowej. Katowice : WYdawnictwo Uniwersytetu Śląskiego w Katowicach, 2015. P. 212-222.

11. Lipscomb V. B. Age in M. Butterfly: Unquestioned Performance. Modern Drama. 2016. Vol. 59. No 2. P. 193-212.

\section{References}

1. Arie, P. (2015). Baba Prisya and other Heroes. Brustury: Discursus [in Ukrainian].

2. Delmar, V. (1978). Far is silence... (K. Rappoport, Trans.). Retrieved from http://bookworm-elibrary.blogspot.com/2012/07/1978-vina-delmar-make-way-for-tomorrow.html [in Russian].

3. Diachenko, L.I. (2009). The aspects of the notion of gerontology in the context of social and philosophical analysis. Vestnik Vyatskogo gosudarstvennogo gumanitarnogo universiteta, 3(4), 21-24 [in Russian].

4. Kirnos, I. (2017). Economic activities of elderly people: a variety of perspectives. Naukovyj visnyk Mizhnarodnogho ghumanitarnogho universytetu, 25-2. Retrieved from http://www.vestnik-econom.mgu.od.ua/journal/2017/25-2-2017/17.pdf [in Ukrainian]

5. Plokhotnyuk, N. (2017). "The Stalkers" or the way the radioactive humor borders with the truth of our life. Vechirnij Kyjiv. Retrieved from https://vechirniykiev.com.ua/news/stalkery-abo-yak-radioaktyvnyy-humor-mezhuye-z-pravdoyu-nashoho-zhyttya [in Ukrainian].

6. Protassova, H. (2016). Pavlo Arie. Baba Prisya and other Heroes. Krytyka. Retrieved from https://krytyka.com/ua/reviews/baba-prisya-ta-inshi-heroyi [in Ukrainian].

7. Ukrajinsjkyj teatr. (2016). Sokolenko N. (Eds.). 3, 1-48 [in Ukrainian]. Ukrainian].

8. Khomenko, K. (2014). Baba Prisya by Pavlo Arie. Retrieved from https://theater-kiev.livejournal.com/26332.html [in

9. Gullette M. M. (2004). Acting Age on Stage. In Aged by culture. Chicago: The University of Chicago Press, 159-178

10. Korzeniowska-Bihun A. (2015). Zona czarnobylska we współczesnej dramaturgii ukraińskiej. Teatr historii lokalnych w Europie Środkowej. Katowice: WYdawnictwo Uniwersytetu Śląskiego w Katowicach, 212-222. [in Polish]

11. Lipscomb V. B. (2016). Age in M. Butterfly: Unquestioned Performance. Modern Drama. 59, 2, 193-212. [in English]. 